\title{
Effects of Industrial Waste on Genetic Variability of Pangasius hypophthalmus in Bangladesh
}

\author{
Md. Alamgir Kabir ${ }^{*}$ and Md. Hasan Faruque \\ Department of Fisheries, University of Dhaka, Dhaka 1000, Bangladesh \\ "(Corresponding Author: Md. Alamgir Kabir, Department of Fisheries, University of Dhaka, Dhaka 1000, \\ Bangladesh, Email:makabir@du.ac.bd)
}

\begin{abstract}
The effects of industrial effluents on genetic variability of Thai Pangas, Pangasius hypophthalmus were examined by seven RAPD primers in this research. Pangasius hypophthalmus were collected from pollution free water bodies of Mymensingh district, Bangladesh as well as from industrial polluted water bodies of Narayanganj district of Bangladesh. Results indicated that, OPS-04 primer showed no band and except primer OPAK-04 other primes shown no polymorphism in Thai Pangas. None but the primer OPAK-04 showed $71.42 \%$ polymorphism along with the average polymorphism of $10.20 \%$ in these two specimens which was very negligible. The cluster analysis followed with the genetic distance (0.1542) and genetic identity (0.8571) clearly indicated a minor diversity in genetic level between the samples collected from Mymensingh and Narayanganj. As one primer showed a negligible polymorphism so may be there could be minor effects on genetic level by industrial effluents but the effects were not prominent.
\end{abstract}

Keywords: Industrial effluents, effects, genetic variability, Thai Pangas, RAPD

\section{Introduction}

Aquaculture is one of the important income sources for Bangladesh where more than fifteen million peoples are directly or indirectly involved ${ }^{[1]}$. Pangasius hypophthalmus known as Thai Pangas, is one of the most commonly cultured freshwater fish in Bangladesh. This fish has been introduced in Bangladesh from Thailand in 1990. This species is omnivorous in food habits and takes crustaceans, mollusks, fish, and vegetable wastes. Mature Thai Pangas contains thick layers of fat. Moreover this fish has high market demand in Bangladesh for the cheap price in common people ${ }^{[2]}$. This fish is also used as sporting fish. They are highly tolerant to the changes in salinity, $\mathrm{pH}$, dissolved oxygen or even pollution. So they are been cultured in that area where the others fishes unable to survive due to pollution or others environmental stress. In Bangladesh they are cultured in industrial polluted area like Hazaribaag or Pagla lagoon in Narayanganj then that fishes are marketed in Dhaka city. There is not enough report on the effects of industrial wastage on the genetic variability of this species. Random Amplification of Polymorphic DNA (RAPD) technique is very fast, simple and sensitive which allows identifying genetic variation without prior knowledge of DNA sequences. RAPD has been widely employed in fisheries studies ${ }^{[3]}$. RAPD can detect the intra specific genetic diversity easily by arbitrary primer analysis. This fishes from polluted area viz. Narayanganj are consumed by the local people in Dhaka city of Bangladesh. Therefore, from the view of human consumption of this fish is needed to identify the effects of pollutant from different industrial waste on their genetic variability. Therefore, this research has been designed to identify the impacts of different industrial wastage on the genetic variability by RAPD markers.

\subsection{Sample Collection}

\section{Materials and Methods}

Experimental fish, Pangasius hypophthalmus were collected from pollutant free water bodies of Mymensingh district of Bangladesh as well as from the water bodies of Narayanganj district, Bangladesh where untreated industrial pollutants are usually discharged in the fish cultured areas.

\subsection{Isolation and Quantification of genomic DNA}

About $30 \mathrm{mg}$ caudal fin from the sampled fish were collected and total genomic DNA was extracted by using a modified CTAB method ${ }^{[4]}$. DNA concentration was quantified by Nano Drop Spectrophotometer (Model: ND2000, Origin: Thermo Scientific, USA). The A260/280 readings for DNA sample was 1.95 and 1.97 collected from Mymensingh and Narayanganj, respectively. 


\subsection{Primer Selection}

Seven primers were tested for RAPD amplification (Operon Technologies, USA and Sigma USA) named OPAW-09 (ACT GGG TCG G), OPAK-04 (AGG GTC GGT C), OPS-04 (CAC CCC CTT G), OPA-09 (GGG TAA CGC C), OPA-03 (AGT CAG CCA C), OPA-04(AAT CGG GCT G) and OPAK-07 (CTT GGG GGA C) exhibited good quality banding patterns and sufficient variability. These primers were selected for further analysis.

\subsection{PCR amplification}

Annealing Temperature was calculated by following equation:

$$
\text { Annealing Temp }=\frac{(\mathrm{Tm} \mathrm{F}+\mathrm{Tm} \mathrm{R})}{2}-(1 \text { to } 5)
$$

The PCR reaction mix for $25 \mu \mathrm{l}$ containing master mix $12.5 \mu$, template DNA (Concentration 25-65 ng/ul) $1 \mu \mathrm{l}$, de-ionized distilled water $9.5 \mu \mathrm{l}$, Primer F ( Concentration 10-20 pMol) $1 \mu \mathrm{l}$, Primer R ( C oncentration 10-20 pMol) $1 \mu \mathrm{l}$. PCR amplification was done for 32-35 cycles after initial denaturing at $95^{\circ} \mathrm{C}$ for $3 \mathrm{~min}$, denaturing at $94^{\circ} \mathrm{C}$ for $30 \mathrm{sec}$, annealing at as listed as above primer list table for $30 \mathrm{sec}$, extension at $72^{\circ} \mathrm{C}$ for $1 \mathrm{~min}$ and final extension at $72^{\circ} \mathrm{C}$ for $5 \mathrm{~min}$.

\subsection{Gel Electrophoresis, Scoring and Data Analysis}

Amplified DNA was run through gel electrophoresis. All the samples showed adequate quantity of DNA produced by PCR amplification. DNA ladders $(1 \mathrm{~kb})$ were electrophoresed alongside the RAPD reactions as marker. DNA bands were observed on UV-trans illuminator and photographed by a gel documentation system. The photographs were critically analyzed on the basis of presence (score 1) or absence (score 0) of band, size of bands and overall polymorphism of the bands. The values of pair-wise genetic distances were analyzed by using computer software "POPGENE 32" (version 1.31).

\subsection{RAPD Analysis}

\section{Results}

Seven primers viz. OPAW-09, OPAK-04, OPS-04, OPA-09, OPA-03, OPA-04, and OPAK-07 produced good quality of banding patterns except OPS-04 which produced no bands between these two Thai Pangas. These primers were selected for further RAPD analysis of two Pangas from polluted area of Narayanganj and the pollutant free area of Mymensingh (Table1).

Table 1. Nucleic acid concentration of different Pangas sample

\begin{tabular}{lccccccc}
\hline Sample ID & $\begin{array}{c}\text { Nucleic Acid } \\
\text { Conc. }\end{array}$ & Unit & A260 & A280 & $260 / 280$ & $\begin{array}{c}\text { Sample } \\
\text { Type }\end{array}$ & Factor \\
\hline Mymenshingh & 28.7 & $\mathrm{ng} / \mu 1$ & 0.573 & 0.295 & 1.95 & DNA & 50 \\
\hline Narayanganj & 25.3 & $\mathrm{ng} / \mu 1$ & 0.507 & 0.257 & 1.97 & DNA & 50 \\
\hline
\end{tabular}

A total of 41 bands were produced of which 5 were polymorphic with only $10.20 \%$ polymorphisms between two Thai Pangas (Figure 1, 2 and Table 2). Only primer OPAK-04 showed 5 polymorphic bands among of its seven total bands and showed $71.42 \%$ polymorphisms where the rest of the primers showed no polymorphism among them.

Table 2. Compilation of RAPD analysis in two Pangasius hypophthalmus with seven different Primers

\begin{tabular}{llcccc}
\hline $\begin{array}{c}\text { Primer } \\
\text { codes }\end{array}$ & $\begin{array}{c}\text { Sequences } \\
\left(5^{\prime}-3^{\prime}\right)\end{array}$ & $\begin{array}{c}\text { Size ranges } \\
(\mathrm{bp})\end{array}$ & Total bands & $\begin{array}{c}\text { Number of } \\
\text { Polymorphic } \\
\text { bands }\end{array}$ & $\begin{array}{c}\text { Polymo- } \\
\text { rphisms } \\
(\%)\end{array}$ \\
\hline OPAW-09 & ACT GGG TCG G & $1000-1200$ & 06 & 00 & 0.0 \\
\hline OPAK-04 & AGG GTC GGT C & $500-1050$ & 07 & 05 & 71.42 \\
\hline OPS-04 & CAC CCC CTT G & No bands & - & - & 0.0 \\
\hline OPA-09 & GGG TAA CGC C & $530-1200$ & 08 & 00 & 0.0 \\
\hline OPA-03 & AGT CAG CCA C & $400-700$ & 06 & 00 & 0.0 \\
\hline OPA-04 & AAT CGG GCT G & $400-1180$ & 06 & 00 & 0.0 \\
\hline OPAK-07 & CTT GGG GGA C & $680-1170$ & 08 & 00 & 0.0 \\
\hline Grand total & & & 41 & 05 & 71.42 \\
\hline
\end{tabular}



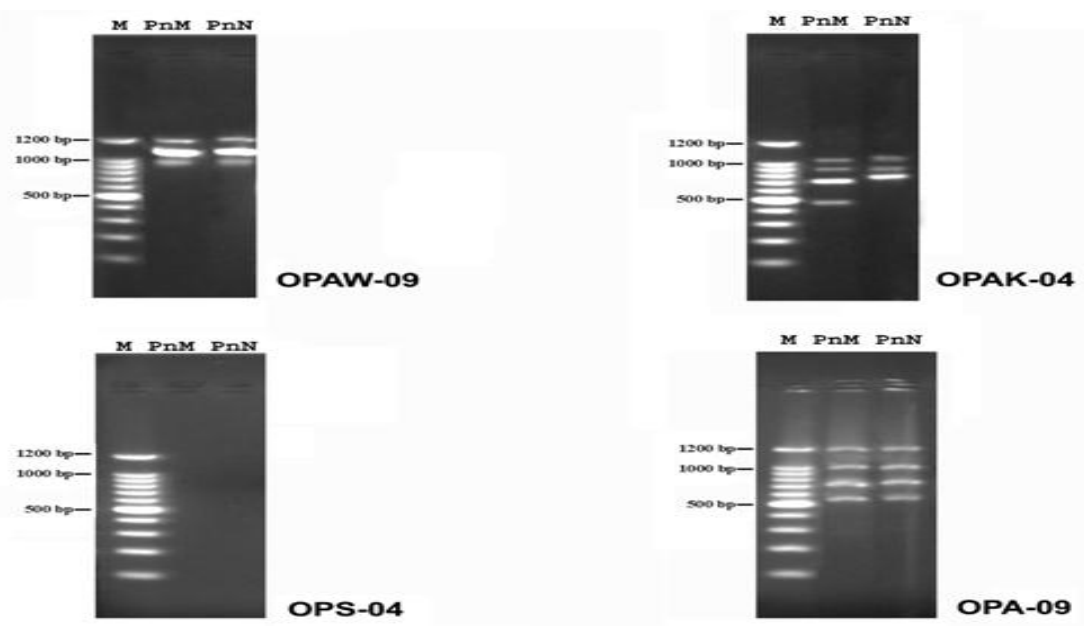

Figure 1. RAPD analysis with four primers of two Pangas from Mymensingh and Narayanganj (M=Ladder, PnM= Pangas from Mymensingh and PnM= Pangas from Narayanganj in Bangladesh).
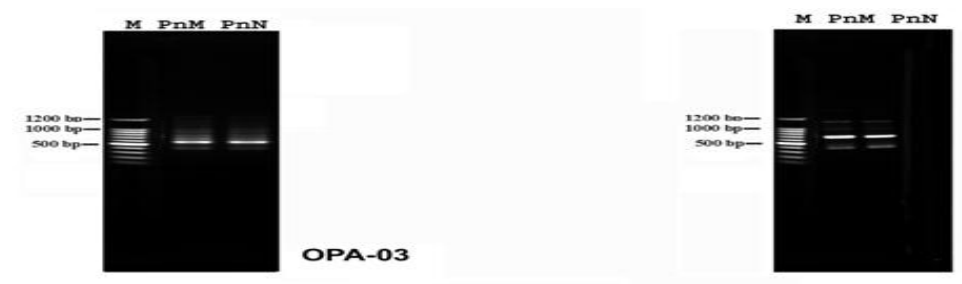

OPA-04

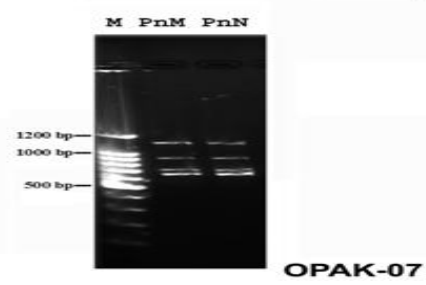

Figure 2. RAPD analysis with three primers of two Pangas from Mymensingh and Narayanganj (M=Ladder, $\mathrm{PnM}=$ Pangas from Mymensingh and PnM= Pangas from Narayanganj in Bangladesh).

\subsection{Genetic Distances and Genetic Identity}

The values of pair-wise genetic distances were analyzed by using computer software "POPGENE32" (version 1.31) from total RAPD fragments. The genetic distance was (0.1542) between them (Figure 3 ). The genetic identity was found as $(0.8571)$ between these two Thai Pangas.

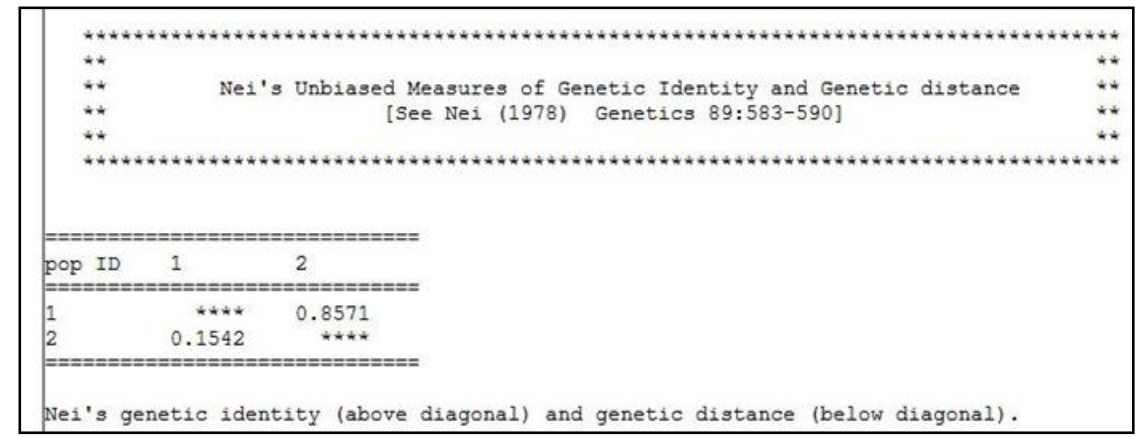

Figure 3. Two Thai Pangas, Pangasius hypophthalmus sampled showed the genetic identity and genetic distance among them. Here Population 1= Mymensing_Pangas which from pollutants free water body, Population 2=Narayangan Pangas which was from polluted water. 


\subsection{Dendogram (Tree diagram)}

Cluster analysis on the basis of DNA fingerprinting by RAPD was carried out. Dendrogram based on ${ }^{[5]}$ genetic distance was constructed using Unweighted Pair Group Method of Arithmetic Means (UPGMA) was separated in two major clusters viz. C1 and C2 (Figure 4).

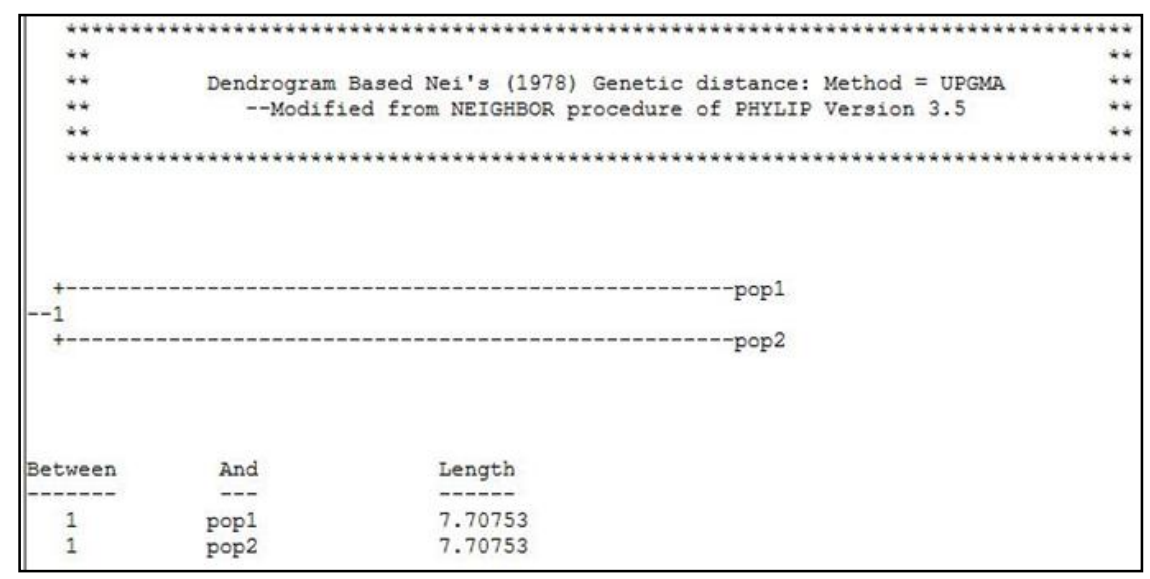

Figure 4. UPGMA dendrogram constructed based on Nei's (1972) genetic distance on differentiation between two different samples of Pangasius hypophthalmus from by RAPD. Here Population 1= Mymensingh_Pangas which from pollutants free water body, Population 2=Narayangan Pangas which was from polluted water

\section{Discussion}

Genetic variability of an organism is an important tool for identification of population changes which is needed for population conservation [ [ ${ }^{6}$. RAPD technique is very easy, fast and sensitive tool for identification of genetic variability of different organism ${ }^{[7]}$. RAPD can be a powerful eco-toxicological tool ${ }^{[8]}$. Nowadays RAPD-PCR technique has been used for the identification of molecular characterization of several organisms. When an organism is used to detect DNA changes produced by environmental genotoxic chemicals DNA banding pattern is essential. RAPD can be used for the examination and estimation of genomic variation in genotoxic studies ${ }^{[9]}$. Different industrial pollutant bears some DNA damaging ingredients which can breakdown the DNA pattern which may have the cytotoxic effects. Sometimes they can changes in oligonucleotide priming sites due to genomic rearrangements ${ }^{[9]}$. Moreover, some studies have reported that RAPD analysis was more sensitive than classic tests such as the comet and micronucleus assay. RAPD analysis is capable of detecting temporary DNA changes at lower concentrations of pollutants that may not finally manifest themselves as mutations ${ }^{[10]}$. In this present research, two different populations were selected from two different area of Bangladesh in which one was from industrial polluted area Narayanganj and the other one was from pollutant free area Mymensing to identify the effects of industrial effluents on them. Two specimen of Pangasius hypophthalmus from Mymensingh and Narayaganj in Bangladesh showed very negligible average polymorphism between them viz. $10.20 \%$ (Table 2) which indicated that they were very close in genetic level but not the exactly same stock. Among the seven primer combinations only one primer OPAK-04 showed polymorphism between them but the OPS-04 showed no bands between these two specimens of Pangas (Fig 1, 2 \& Table 2). Some earlier researcher reported different polymorphism worked on Pangasius sp and others cat fishes as followed, the average polymorphism among Pagasianodon gigas, P. hypophthalmus and their hybrids was reported as $65.38-100 \%$ with 20 different primer combinations, using amplified fragment length polymorphism markers ${ }^{[11]}$, besides this among the different cat fish, the polymorphism was reported as in $C$. gariepinus populations of $82.35 \%$ polymorphism ${ }^{[12]}, 64.98 \%$ polymorphism in Mystus vittatus ${ }^{[13]}, 20.55 \%$ polymorphism in Yellow Catfish Horabagrus nigricollaris [14] 26.5 to $30.5 \%$ polymorphism in Clarius batracus $^{[15]}, 56.4$ to $59.6 \%$ polymorphism between two populations of Clarius batracus ${ }^{[16]}$ and $78.15 \%$ polymorphism in Mystus vittatus ${ }^{[17]}$. Here no polymorphism is likely to represent the polymorphism of present study viz. $10.20 \%$. The changes in DNA banding pattern by RAPD can be the results of genetic material changed. The efficiency of DNA repair and replication and DNA damage are directly related to genomic template ${ }^{[18]}$. The genomic template stability may be related to different kinds of DNA damage, such as DNA adducts, mutations, rearrangements which can be the results of different pollutants ${ }^{[9]}$. As in the present study no 
major differences were found between the DNA profiling of two pangas specimen from polluted and pollutant free area by RAPD may be the minor effects of pollutant in DNA level. A little polymorphism viz. $10.20 \%$ indicated that there is little bit effects on DNA of these specimen but not the major, may be due to temporary effects of industrial effluents on DNA of Pangasius hypophthalmus.

\section{Conclusion}

The findings of this research have been showed that these two specimens have no major differences between them by PCR-based RAPD molecular technique. May be there was no prominent effects of industrial effluent on DNA level of these two varieties. From genetic distance (0.1542) and genetic identity (0.8571) it's clear that they were closely related but not the same stock. As the only one primer OPAK-04 showed somewhat polymorphism so may be there could be minor effect on genetic level by industrial effluent.

\section{Acknowledgements}

This paper is based on a research funded by Centre for Advanced Studies and Research in Biological Sciences, University of Dhaka. We also like to thank Professor Dr. Sheikh Shamimul Alam, Department of Botany, University of Dhaka for his constructive criticisms to carry out this research.

\section{References}

[1] FRSS, Fisheries Statistical Report of Bangladesh. Fisheries Resources Survey System (FRSS), Department of Fisheries, Bangladesh, Volume 31: 57pp

[2] M.M. Rahman, M.S. Islam, G.C. Halder, and M. Tanaka, Cage culture of sutchi catfish, Pangasius sutchi (Fowler 1937): effects of stocking density on growth, survival, and yield and farm profitability, Aquaculture Research, 37(1), 2006, 33-39.

[3] S. Akter, S. Sultana, M.S.R Khan, M. Nahiduzzaman, M.A.R. Hossain, and M.S. Alam, Genetic characterization of critically endangered Puntius sarana (Hamilton) and the exotic Barbonymus gonionotus (Bleeker) (Cyprinidae: Cypriniformes) by DNA Fingerprinting, International Journal of BioSciences, Agriculture and Technology, 2(3), 2010, 21-27.

[4] J.J. Doyle, and J.L. Doyle, A rapid DNA isolation procedure from small quantities of fresh leaf tissues, Phytochem Bull, 19, 1987, 11-15.

[5] M. Nei, Genetic distance between populations, American Naturalist, 106, 1972, 283-292.

[6] N.M. Belfiore, and S.L. Anderson, Effects of contaminants on genetic patterns in aquatic organisms: A review, Mutation Research/Review in. Mutation Research., 489 (2), 2001, 97-122.

[7] R.K.. Garg, P. Sairkar, N. Silawat,and N.N. Mehrotra, Genetic polymorphism of two populations of catfish Aorichthys seenghala (Sykes) using RAPD fingerprinting, International Journal of Integrative Biology, 3, 2009, $130-134$.

[8] S. Unyayar, A. Celik, F.O. Cekic, and A. Gozel, Cadmium induced genotoxicity, cytotoxicity and lipid peroxidation in Allium sativum and Vicia faba, Mutagenesis, 21(1), 2006, 77-81

[9] L. Rocco, I.V. Valentino, G. Scapigliati, and V. Stingo, RAPD-PCR analysis for molecular characterization and genotoxic studies of a new marine fish cell line derived from Dicentrarchus labrax, Cytotechnology, 66 (3), 2014, $383-393$.

[10] W. Liu, P, Li, X. Qi, Q. Zhou, T. Sun, Y. Yang, DNA changes in barley (Hordeum vulgare) seedlings induced by cadmium pollution using RAPD analysis, Chemosphere, 61(2), 2005, 158-167

[11] N. Sutthi, D. Amornlerdpisan, S. Mekchay, and K. Mengumphan, Identification of Pagasianodon gigas, P. hypophthalmus and their hybrids using amplified fragment length polymorphism markers, Maejo international journal of science and technology, 8(3), 2014, 240-250

[12] E.V. Ikpeme, O.U. Udensi, U.B. Ekaluo, M.E. Kooffreh, C.M. Okolo, P.B. Ekpo, and N.C. Ogbonna, Unveiling the genetic diversity in Clarias gariepinus (Burchell, 1822) using random amplified polymorphic DNA (RAPD) fingerprinting technique, Asian Journal of Animal Sciences 9(5), 2015, 187-197.

[13] R.K. Garg, N. Silawat, P.Sairkar, N. Vijay, and N.N. Mehrotra, RAPD analysis for genetic diversity of two populations of Mystus vittatus (Bloch) of Madhya Pradesh, India, African Journal of Biotechnology, 8(17), 2009, 4032-4038.

[14] P.M.A.Muneer, R. Sivanandan, A. Gopalakrishnan, V.S. Basheer, K.K. Musammilu, and A.G, Ponniah, Development and characterization of RAPD and microsatellite markers for genetic variation analysis in the critically endangered yellow catfish Horabagrus nigricollaris (Teleostei: Horabagridae), Biochemical Genetics, 49 (1-2), 2011, 83-95.

[15] G.D. Khedkar, A.C.S. Reddy, P. Mann, K. Ravinder, and K. Muzumdar, Clarias batrachus (Linn. 1758) population is lacking genetic diversity in India, Molecular biology reports, 37(3), 1355-1362.

[16] M. Danish, I.J. Singh, P. Giri, and C.P. Singh, Molecular characterization of two populations of catfish Clarias batrachus L. using random amplified polymorphic DNA (RAPD) markers, African Journal of Biotechnology, 11(77), 2012, 14217-14226.

[17] I. Hasan , and M.M. Goswami, Genetic Variation among Cat Fish (Mystus vittatus) Population assessed by randomly amplified polymorphic (RAPD) markers from assam, India, Journal of Aquaculture Research and Development, 6(4), 2015.

[18] L. Rocco, A. Izzo, G. Zito, C. Peluso, V, Stingo, Genotoxicity in zebrafish (Danio rerio) exposed to two pharmacological products from an impacted Italian river, Journal of Environmental \& Analytical Toxicology, l 1, 2011. 